\title{
5-15-2015
}

\section{Film Review: E-Team}

Rafiki Ubaldo

Hugo Valentin Centre, Uppsala University

Follow this and additional works at: https://digitalcommons.usf.edu/gsp

\section{Recommended Citation}

Ubaldo, Rafiki (2015) "Film Review: E-Team," Genocide Studies and Prevention: An International Journal: Vol. 9: Iss. 1: 125-127.

DOI:

http://dx.doi.org/10.5038/1911-9933.9.1.1332

Available at: https://digitalcommons.usf.edu/gsp/vol9/iss1/15

This Film Review is brought to you for free and open access by the Open Access Journals at Digital Commons @ University of South Florida. It has been accepted for inclusion in Genocide Studies and Prevention: An International Journal by an authorized editor of Digital Commons @ University of South Florida. For more information, please contact digitalcommons@usf.edu. 
Film Review: E-Team

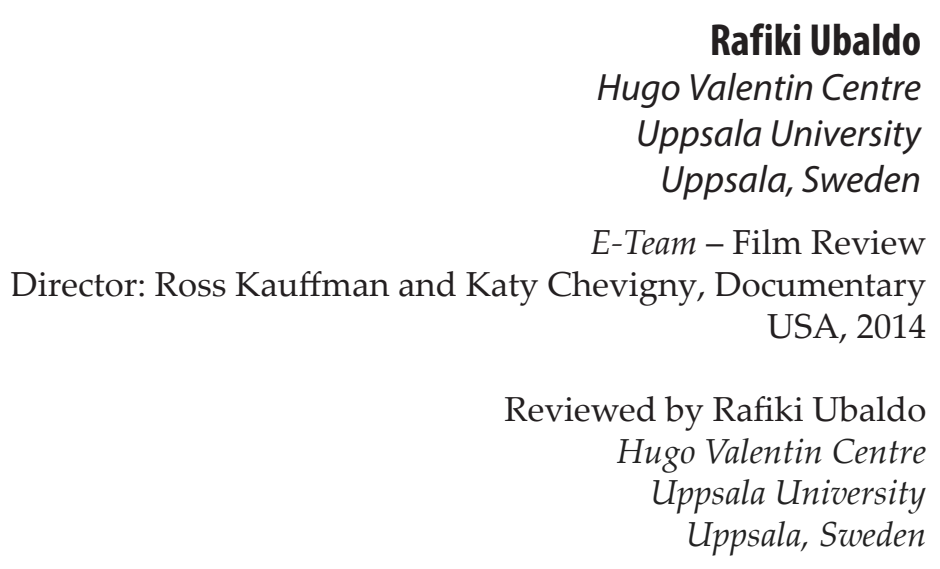

Anna, Ole, Peter, and Fred "are members of the Emergencies Team, or The E-Team, a division of Human Rights Watch ... trained to deal with unfolding crises, document war crimes and report them to the world". ${ }^{1}$ Using a cinéma vérité approach, Ross Kauffman and Katy Chevigny, two award-winning filmmakers, follow The E-Team in the field in Syria and Libya.

First, Anna and Ole are absorbed in reviewing the complex plan to smuggle them into Syria to investigate and document the crimes being committed. They cross the border into Syria illegally, and the camera filming them walks the viewer through images of ruined building and empty streets - empty except for a couple of street vendors manning blueberries stands and a few children running around. Then Anna and Ole walk into someone's home to interview family members about crimes they witnessed and/or relatives they lost. Destruction and despair are there to be seen.

In the middle of the interview a heavy sound of a passing plane, probably a jet bomber, provokes commotion in the home, interrupting the interview, and everyone takes shelter; but the camera keeps rolling to give us foggy images of scared movements and worried voices. Members of the interviewees' family lament: "What is our crime? What have we done [for bombs to be dropped on our homes like this]?" The interview goes on in spite of the pain and fear visible in the face of the interviewee. Question after question, the E-Team members do their possible best to establish facts and responsibilities. This one scene highlights the work the investigators can do, sometimes conducting multiple interviews about one and the same incident. E-team members have to answer questions such as what exactly happened in one place, and why and how to conclude that, based on their findings, a violation of international law has occurred. On other occasions, such as in the scenes of bombs falling on the Syrian town of Azaz, Anna and Ole witness crimes being committed at the same time that they are conducting investigations to ascertain who is responsible for the destruction.

In the case of Libya, Peter and Fred arrived at the crime scenes after the killing of Gadhafi. They came at the right time to witness large quantities of sophisticated weaponry abandoned in the desert, and a sea of secret documents the Gadhafi regime was not able to destroy before its demise. Peter's expertise in weaponry allowed for the possibility of determining the provenance of Gadhafi's weapons. Additionally, Fred's vast experience in tracking violations of human rights helped Human Rights Watch conduct detailed analyses of the documentation left behind by Gaddafi's secret services.

The Emergencies Team enjoys a consistent following among mainstream newspapers and television channels in the Global North. Filmmakers Ross Kauffman and Katy Chevigny take viewers back to the Balkan Wars of the 1990s to explain the birth and subsequent success of The Emergencies Team. In September 1998, Fred and his colleagues visited the Balkans to document human rights violations. One evening Fred was informed about ongoing killings in the Gornje Obrinje region in Kosovo. He was urged to go there and see for himself. Instead of following 
the tradition at Human Rights Watch to collect data and go back to New York and produce a report, he wrote a press release, and shared it with the media. That story made headlines in major newspapers in the United States of America and led decision makers, including the White House, to take action to intervene and stop the killings in Kosovo. In 2002, Fred, by now considered the Father of The Emergencies Team, testified in the Milošević case before the International Criminal Tribunal for the former Yugoslavia (ICTY) in The Hague.

Kauffman and Chevigny's research into the ICTY video archives and the particular material they chose to use in this film serve the claim that cinéma vérité aims at projecting "something that really happens, and the method by which the film was made-which defines a role for the filmmaker in filming the scene as it unfolds - seems to ensure the authenticity of the scene." 2 The encounter between Milošević and Fred during the court proceedings at the ICTY is not a natural setting in itself. Courtrooms are arranged settings in which interactions and interventions are more or less regulated in order for the judges to accomplish their tasks of hearing different parties to trials. However, when Milošević intervenes to accuse that Human Rights Watch has shown determination to have him arrested and tried, he provides Fred with a spontaneous opportunity to defend the organization: "We do not start with an end result, or a conclusion, or an aim, and then search for the facts that will lead to that conclusion. We start with research in the field that leads us up to the end." Furthermore, Milošević's accusations against Human Rights Watch awakened Fred's attention to direct his candidness towards the judges and respond in the strongest and clearest terms. The camera captured that spontaneous and strong appeal to provide one of those rare scenes where cinéma vérité approaches succeed "in filming people without making them appear manipulated or self-conscious." ${ }^{3}$ In order to know more about what it was like to testify against Milošević, Kauffman and Chevigny decide to interview Fred. While trying to formulate his answer, Fred struggles to hide tears; he swallows them to clear his throat-one may say-and declares: "I honestly felt like I had a responsibility that every person who told me their story, and lived through this horrible experience, that I now owe them their moment in court. And this was a chance to represent them."

Other episodes allow critical views to be voiced when the E-Team members meet skeptics. In Moscow, for example, Anna goes to launch the Human Rights Watch report on Syria, with the hope of convincing the Russian government to stop supporting the Syrian government. According to Human Rights Watch reports, the Syrian government is largely responsible for ongoing human rights violations in the country. During the question-and-answer session, a journalist suggested that Anna works for an organization that is not independent, but rather is an agent of American imperialism. In another episode, and during a mission to investigate Human Rights violations in Libya, a rebel leader tells Peter that his organization cannot be fully reliable because it changes alliances as soon as the people it used to defend gain power. Such episodes prevent the film from being a public relations production on behalf of Human Rights Watch. Instead, by allowing critical voices to be heard in the film - thus highlighting the complexities of issues human rights defenders face-Kauffman and Chevigny realize a powerful plaidoyer for the different organizations that take risks to sound the alarm against violations of human rights.

An additional but equally important element that makes this film a success is the art of capturing negotiations of normality in times of war. In the E-Team, the war does not manifest itself through bombs and fighting in Syria or Libya. For Anna, Ole, Peter and Fred the war is experienced during the investigating violations of human rights in the field, living among the victims, trying to cope with life with them, but it does not end there. The war continues for them when these investigators go back to Paris, Berlin, or any other city in the peaceful West. They carry the war with them for as long as they keep working on a case. Their search for normality can best be described through anthropologist Ivana Macek's understanding of negotiating normality in times of war and/or mass violence: "patching together a semblance of existence, living from day to day on terms [one] could neither finally accept nor directly deny." ${ }^{\prime 4}$

Macek was able to directly experience the siege of Sarajevo during which she collected data about lives of people who were affected by the violence as the war went on. She observed that people felt humiliated and ashamed because they could not live as decently as they used to, or could not avoid depending on foreign aid in order to make it through the war. ${ }^{5}$ Yet they were 
inventive and proud enough to create all sorts of ways and tools to ensure a life reminiscent of the normality of the pre-war times. ${ }^{6}$

Humiliation, shame, inventiveness and pride happen in the lives of The E-team members as well. When they succeed in exposing crimes they feel pride and show it. When they fail to garner a desired attention, or when the camera records long moments of silence, and faces lost in some thoughts, it is as if they are ashamed of not solving problems, or realizing that the victims do not enjoy the luxury of escaping that madness while they will go back to Paris, New York, Berlin, or Geneva.

Anna and Ole are not only teammates; they are also a married couple. At one occasion, their wedding anniversary happens while they are in war torn Syria. Instead of giving in to the desolation and destruction around them and postpone their celebration, they find ways to live as normally as possible under the circumstances. Ole gets a haircut, Anna makes herself beautiful, and they wish each other a happy anniversary. On another occasion, Ole and Anna are traveling inside Syria with their local colleague and translator. He mentions to them that his wife is pregnant. The pregnancy is still in its early stage but he is so excited that he counts every day that passes.

How could one possibly have a child at a time they are witnessing and/or witnessing mass violence? Kauffman and Chevigny do not ask that question in the film, but they provided us with a magnificent work that provokes that question in us. Therein lies the importance of their film: helping us realize that we constantly negotiate going back and forth between conditions we can neither completely accept nor completely refuse. With the E-Team, the picture of the unparalleled human capacity to destroy provokes revolt; at the same time, one is baffled and inspired by the picture of human ability to overcome war, mass violence, or genocide, and survive to give lifeagain.

Title of the Film: E-Team; Directors: Katy Ross Kauffman and Chevigny; Producer: Marilyn Ness; Cinematography: Rachel Beth Anderson, James Foley, Ross Kauffman; Film Editing: David Teague; Country: USA; Year of Release: 2014; Production Company: Big Mouth Productions, Red Light Films, in association with Impact Partners. Duration: 88 minutes.

\section{Endnotes}

1 About E-Team: http://www.eteamfilm.com/\#!film/cx7j; see also E-Team, http://ff.hrw.org/film/eteam?city $=185$, last accessed January $3^{\text {rd }}, 2015$

2 William Rothman, The "I" of the camera: essays in film criticism, history, and aesthetics, 2nd Ed. (New York: Cambridge University Press, 2004).

3 Ibid.

4 Ivana Macek, Sarajevo Under Siege: Anthropology in Wartime (Philadelphia: University of Pennsylvania Press, 2009).

5 Ibid. 66-67

6 Ibid. 71-77 